\title{
SISTEMAS PROCESSUAIS PENAIS: UMA ANÁLISE CRÍTICA DO SISTEMA BRASILEIRO ${ }^{1}$
}

\section{PROCEDURAL CRIMINAL SYSTEMS: A CRITICAL ANALYSIS OF THE BRAZILIAN SYSTEM}

\section{Rafael Khalil Coltro}

Mestre em Direito pelo Centro Universitário das Faculdades Metropolitanas Unidas - FMU- SP. Especialista em Direito Penal e Criminologia pela Pontifícia Universidade Católica do Rio Grande do Sul - PUC-RS. Advogado e membro da Comissão de Direito Penal da OAB/SP. São Paulo/SP. E-mail: rkcoltro@gmail.com

RESUMO: O presente artigo busca fazer uma análise crítica acerca do funcionamento atual do sistema processual penal brasileiro, sendo que, em um primeiro momento, o artigo introduz, de forma sintetizada, quais são os principais sistemas processuais penais que são mais comumente estudados pela doutrina, denominados Sistema Acusatório, Sistema Inquisitório e Sistema Processual Misto, elucidando quais são as diferenças entre os três sistemas processuais penais, para, a partir de então, realizar uma abordagem crítica sobre qual o sistema processual penal adotado no Brasil e, por fim, analisar se a sua aplicabilidade vem sendo exercida dentro dos ditames estipulados pela carta magna de 1988.

PALAVRAS-CHAVE: Sistemas Processuais Penais; Sistema Acusatório; Sistema Inquisitório; Sistema Misto; Processo Penal.

\begin{abstract}
The present paper aims to discuss about the current functioning of the Brazilian criminal procedural system. In a first moment, the article introduces, in a synthesized way, which are the main criminal procedural systems that are most commonly studied by the doctrine, called Accusatory System, Inquisitorial System and Mixed
\end{abstract}

\footnotetext{
${ }^{1}$ Artigo recebido em 19/03/2021 e aprovado em 26/07/2021.
} 
Procedural System, elucidating the differences between the three criminal procedural systems, to, from then on, carry out a critical approach on which is the criminal procedural system adopted in Brazil, and, finally, seeks to analyze if its applicability has being exercised within the dictates stipulated by the 1988 Constitution.

KEYWORDS: Criminal Procedural Systems; Accusatory System; Inquisitorial System; Mixed System; Criminal Proceedings.

\section{Introdução.}

Para adentrar na temática tida como objeto do presente no artigo, primeiro será necessário realizar uma exposição, mesmo que de forma sintetizada, a respeito da definição jurídica de "sistema" e de quais são os principais sistemas processuais penais mais comumente estudados pela doutrina, os quais, são denominados Sistema Acusatório, Sistema Inquisitório e Sistema Processual Misto, elucidando objetivamente quais são as diferenças entre os três sistemas processuais penais.

Assim, uma vez compreendidas as principais diferenças entre os referidos sistemas processuais, passa-se a ser possível examinar melhor o sistema processual penal brasileiro, no que será notável a existência de diferentes correntes doutrinárias que divergem acerca de qual sistema processual penal é o vigente atualmente no Brasil. Nesse sentido, o artigo traz ao conhecimento os diversos prismas doutrinários acerca do assunto, explicando que, no Brasil, parte da doutrina reconhece o sistema processual penal brasileiro como um sistema misto; outra parte, aponta o sistema brasileiro como um sistema acusatório; e há ainda, uma terceira linha doutrinária, que identifica no sistema brasileiro a predominância do sistema inquisitório.

Após essa análise voltada para os argumentos doutrinários das diversas correntes, é possível então proceder com uma análise crítica da problemática em questão, através da elucidação dos pontos mais relevantes das linhas doutrinárias para fundamentar uma posição. Além disso, o artigo também faz uma sucinta comparação entre o Código de Processo Penal brasileiro e o chileno, uma vez que o do Chile passou por recentes e 
profundas reformas processuais, voltadas para a adequação do sistema processual infraconstitucional com a legislação constitucional daquele país.

Como será elucidado, no exemplo chileno, deixou-se de lado a realização de reformas processuais pontuais e adotou-se uma reforma profunda, com o intuito de modificar os alicerces fundantes daquele ordenamento jurídico. Assim, em sua parte final, o artigo pretende demonstrar se as mudanças pontuais que vêm sendo realizadas no ordenamento jurídico brasileiro são suficientes para alinhar a antiga legislação processual penal aos ditames previstos na carta magna de 1988.

No que concerne à metodologia, o texto se revela como um estudo bibliográfico com colheita de dados e de citações doutrinárias de modo qualitativo, além de breves análises utilizando-se de direito comparado, tendo como paradigma o sistema processual penal chileno. Após esse estudo crítico e comparativo, o artigo apresenta seus resultados e hipóteses, obtidos essencialmente por indução.

\section{Os Sistemas Processuais Penais.}

Em que pese o objeto central do presente artigo ter como foco a realização de uma análise direcionada para a efetividade do sistema acusatório no processo penal brasileiro, não há como iniciar essa análise sem introduzir, ainda que brevemente, sobre o conteúdo dos principais sistemas processuais penais tradicionalmente estudados pela doutrina, ou seja, os sistemas acusatório, inquisitório e misto. Entretanto, antes de adentrar na análise destes sistemas normativos, resta imperioso elucidar qual o viés que, no presente artigo, atribui-se à palavra "sistema".

No Dicionário de Ciências Sociais da Fundação Getúlio Vargas², define-se sistema como um "Conjunto de coisas que ordenadamente entrelaçadas contribuem para determinado fim; trata-se portanto de um todo coerente cujos diferentes elementos são interdependentes e constituem uma unidade completa"

Etimologicamente falando, portanto, um sistema jurídico compreende um conjunto de normas e de fundamentos interligados, e que funcionam como uma só estrutura normativa

\footnotetext{
${ }^{2}$ FUNDAÇÃO GETÚLIO VARGAS. Dicionário de Ciências Sociais da Fundação Getúlio Vargas. Rio de Janeiro: FGV, 1986, p. 1127.
} 
que dita as diretrizes a serem seguidas para a aplicação do direito. Um sistema não é um conjunto de normas esparsas e desarticuladas, ao contrário, se trata de um "conjunto de normas jurídicas acomodadas numa justaposição que se associam e permitem o movimento harmônico e permanente do regramento pela interpretação e aplicação de suas disposições"3

Assim, um sistema processual deve deter um conjunto de normas que funcionem em sintonia, de forma coerente e uníssona, baseada sempre sob uma mesma base principiológica. E é esta base principiológica que difere os sistemas processuais idealizados pela doutrina.

Como bem observa Geraldo $\operatorname{Prado}^{4}$, a compreensão de um fenômeno jurídico guarda extrema ligação com o contexto espaço-temporal em que o referido fenômeno se encontra inserido. Explica o autor, que "o conhecimento do Direito seria impossível sem o conhecimento do lugar que ocupa no estudo da evolução jurídica."

Ou seja, reconhecidamente, para se compreender os sistemas processuais penais em toda sua amplitude, é preciso também realizar uma análise histórica e social acerca do contexto social que os referidos sistemas foram criados e estiveram ou estão inseridos. Certamente que, dada a limitação do presente estudo, o foco do artigo será direcionado basicamente à estrutura dos sistemas, buscando ressaltar os aspectos processuais característicos em cada um deles, para então passar à análise crítica da questão no Brasil.

Assim, seguindo uma linha de evolução cronológica e iniciando pelo sistema acusatório, este foi o sistema processual predominante na antiguidade e no início da idade média, perdurando como sistema processual penal dominante até meados do século XII, quando passou a ser gradativamente substituído pelo sistema inquisitório, que restou em plena vigência até meados do séculos XVIII. A partir de então, como explica Aury Lopes $\mathrm{Jr}^{5}$. passou-se a verificar uma mescla cada vez maior nos sistemas processuais mundo afora, passando-se, daí, a utilizar-se a afirmação de que um sistema processual poderia ser "misto".

Como se verá a seguir, de forma geral, tradicionalmente, a distinção entre os sistemas acusatório e inquisitório é traçada com base na titularidade do órgão acusatório, sendo que no Sistema Inquisitório, as funções de acusação e de julgamento estariam centralizadas em

\footnotetext{
${ }^{3}$ ROCHA, Cármem Lúcia Antunes. O Princípio Constitucional da Igualdade. Belo Horizonte: Lê, 1990, p. 18.

${ }^{4}$ PRADO, Geraldo. Sistema Acusatório. A conformidade constitucional das Leis Processuais Penais. 3 ed. Rio de Janeiro: Lumen Juris, 2005, p. 111/112.

${ }^{5}$ LOPES JÚNIOR, Aury. Direito Processual Penal. 15 ed. São Paulo: Editora Saraiva Educação, 2018, p. 41.
} 
um só indivíduo, já no Sistema Acusatório, o papel de acusação e o de julgamento são exercidos por pessoas ou órgãos distintos ${ }^{6}$.

Passa-se, então à análise dos sistemas.

\subsection{Sistema Processual Penal Inquisitório.}

Como explica Prado ${ }^{7}$, o Sistema Inquisitório tradicionalmente passa a ser observado pela doutrina como, de fato, um sistema processual penal, por volta do século XIII, quando começa a substituir os sistemas que eram mais ou menos baseados em um modelo acusatório. Nesse sentido, o autor explica que muito embora os séculos XIII e XIV marquem o início da predominância do modelo inquisitorial, transplantado para a justiça laica com o fortalecimento das monarquias e, consequentemente, com a formação do conhecido EstadoNação e a centralização do poder secular, a estrutura acusatória vigente naquela época passou a render-se a aspectos quase sempre identificados no procedimento inquisitório, tais como a forma escrita da dedução da acusação e o segredo que envolvia a produção da prova testemunhal, chegando, pois, ao emprego da tortura, a culminância das presunções e da confissão. Durante certo período, ainda coexistiram na Europa os dois modelos de sistema processual, mas, por fim, o equilíbrio entre os dois modelos se rompe e o sistema inquisitório vive seu apogeu no continente europeu, até ser descartado, ao menos na Europa Ocidental, no século XIX.

Aragoneses Alonso $^{8}$ explica que, no sistema inquisitório, imperava o sistema hierarquizado de valoração de provas (sistema legal de provas ou de prova tarifada), ou seja, cada prova já possuía seu valor definido em lei, sendo que, nesse sistema, o juiz não possuía liberdade para valorar as provas de acordo com as especificidades do caso concreto. Menciona também que no referido sistema processual, a prisão do acusado no transcurso do processo, ou seja, antes do processo de formação de culpa e de ser declarado oficialmente culpado, era a regra e não a exceção.

\footnotetext{
${ }^{6}$ PACHELLI DE OLIVEIRA, Eugênio. Curso de Processo Penal. 11 ed. Rio de Janeiro: Lumen Juris, 2009, p.4.

${ }^{7}$ PRADO, Geraldo. Sistema Acusatório. A conformidade constitucional das Leis Processuais Penais. 3 ed. Rio de Janeiro: Lumen Juris, 2005, p. 139-140.

${ }^{8}$ ARAGONESES ALONSO, Pedro. Curso de Derecho Procesal Penal. V. 1. 4 ed. Madrid: Prensa Castellana, 1974, p. 42.
} 
Bastante relevante ressaltar o que leciona Lopes $\mathrm{Jr}^{9}$., que menciona que no sistema inquisitório, é possível observar a ocorrência de uma aglutinação de funções nas mãos do juiz, que funciona basicamente como o encarregado, ao mesmo tempo, de acusar e de julgar o acusado. Ou seja, como explica o autor, não existe imparcialidade, pois a mesma pessoa (juiz) busca a prova e decide a partir da prova que ele mesmo produziu. Nesse sentido, também discorre Jacinto Coutinho ${ }^{10}$, que explica que, ao juiz inquisidor, cabe o mister de acusar e julgar, simultaneamente.

Assim, em suma, o sistema inquisitório possui como principais características: a iniciativa probatória nas mãos da mesma pessoa/órgão que irá julgar; ausência de separação de funções de quem irá acusar e quem irá julgar; possibilidade do juiz de exercer sua atuação de ofício, sem provocação de um órgão acusatório; parcialidade do juiz; inexistência de contraditório pleno e desigualdade de armas notável.

Diante dessas peculiaridades supramencionadas, o sistema inquisitório passou a ser visto com maus olhos e a ser desacreditado como um sistema justo, por incidir naquilo que Lopes Jr., citando a obra Problemas Jurídicos y Políticos del Proceso Penal, de James Goldschmidt, chama de "erro psicológico por parte do julgador", uma vez que "seria psicologicamente impossível que uma mesma pessoa realize tarefas tão antagônicas como investigar, acusar, defender e julgar, de forma imparcial" ${ }^{11}$.

Assim, os novos postulados de valorização do homem e os movimentos filosóficos do final do século XVIII e início do XIX, passaram a suplantar o sistema processual penal inquisitório, iniciando-se uma lenta transição para o sistema acusatório/misto.

\subsection{Sistema Processual Penal Acusatório.}

O sistema acusatório, por sua vez, apresenta como principal característica a existência de clara distinção e separação entre as atividades acusatórias e jurisdicionais, delimitando e diferenciando o agende que será incumbido de acusar do que realizará o

\footnotetext{
${ }^{9}$ LOPES JÚNIOR, Aury. Direito Processual Penal. 15 ed. São Paulo: Editora Saraiva Educação, 2018, p. 42. ${ }^{10}$ COUTINHO, Jacinto Nelson de Miranda. O papel do novo juiz no processo penal. In: Crítica à teoria geral do direito processo penal. Rio /de Janeiro: Renovar, 2001, 18.

${ }^{11}$ LOPES JÚNIOR, Aury. Direito Processual Penal. 15 ed. São Paulo: Editora Saraiva Educação, 2018, p. $42-$ 43.
} 
julgamento da questão. Como explica Giovanni Leone ${ }^{12}$, de uma forma bastante sintetizada, no referido sistema processual o poder de decisão é entregue a um órgão estatal diverso daquele que detém o poder de iniciativa do processo, dessa forma, o magistrado "se libera da vinculação às iniciativas do autor, impulsionando oficialmente a persecução penal, que se desenvolverá conforme os princípios do contraditório, com paridade de armas, oralidade e publicidade" ${ }^{\prime \prime}$.

Conforme explica Lopes $\mathrm{Jr}^{14}$, a forma processual acusatória detém, entre outras características, como destaque: a separação entre o acusador e o julgador; a iniciativa probatória deve ser das partes (acusação e defesa); adoção do papel do juiz como um terceiro imparcial, alheio à investigação e à produção de provas; ausência de valoração hierárquica das provas, sustentando-se a decisão do juiz pelo livre convencimento motivado.

Ademais, no sistema acusatório dá-se especial importância à imparcialidade do julgador, sendo tal requisito um dos mais importantes destaques desse sistema processual penal. Além disso, é dada especial importância ao direito ao contraditório, este muito desvalorizado e até desincentivado do sistema inquisitório, sendo "absolutamente incompatível com o sistema acusatório a prática de atos de caráter probatório ou persecutório por parte do juiz"15.

O sistema acusatório vem sendo encarado como o mais correto na esmagadora maioria das sociedades democráticas ocidentais, por ser o mais alinhado com os direitos humanos internacionais e com o que preceitua a teoria do garantismo penal ${ }^{16}$, que preza pela manutenção dos direitos fundamentais como norte para o funcionamento de um Estado Democrático de Direito.

\subsection{Sistema Processual Penal Misto.}

\footnotetext{
${ }^{12}$ LEONE, Giovanni. Manuale di Diritto Processuale Penale. Napoli: Jovene, 1983, p. 8.

${ }^{13}$ PRADO, Geraldo. Sistema Acusatório. A conformidade constitucional das Leis Processuais Penais. 3 ed. Rio de Janeiro: Lumen Juris, 2005, p. 170.

${ }^{14}$ LOPES JÚNIOR, Aury. Direito Processual Penal. 15 ed. São Paulo: Editora Saraiva Educação, 2018, p.43.

${ }^{15}$ CUNHA MARTINS, Rui. O Ponto Cego do Direito. Rio de Janeiro: Lumen Juris, 2010.

${ }^{16}$ Sobre o assunto: FERRAJOLI, Luigi. Direito e razão: teoria do garantismo penal. 2 ed. São Paulo: Revista dos Tribunais, 2006.
} 
O chamado "sistema processual Misto" surge após o aparecimento do conceito de divisão do processo criminal em duas fases: a pré-processual e a processual, sendo a primeira de características inquisitórias e a segunda acusatórias.

Segundo explica Guilherme Nucci ${ }^{17}$, sintetizando uma série de outros autores, essa divisão do processo penal em duas fases possibilitaria o predomínio, em geral, da forma inquisitiva na fase preparatória e acusatória na fase processual, o que acarreta o surgimento de um sistema processual misto, que une características de ambos os sistemas processuais penais tradicionais.

Em sentido diverso, vem a crítica trazida por outra corrente doutrinária ${ }^{18}$, que menciona que afirmar que um sistema é "misto" trata-se de um "reducionismo ilusório", pois não existem mais sistemas processuais puros, todos são mistos, sofrendo influências dos sistemas acusatórios e inquisitórios. Segundo essa parte da doutrinária, não é possível existir um sistema misto. Para essa linha, é necessário identificar qual o "núcleo regente” do sistema processual penal e, uma vez identificado, é possível determinar se o sistema é alicerceado em princípios inerentes ao sistema acusatório ou ao sistema inquisitório. Nesse sentido, explica Lopes Jr., ao dizer que, "é necessário identificar o princípio informador de cada sistema, para então classificá-lo como inquisitório ou acusatório, pois essa classificação feita a partir de seu núcleo é de extrema relevância." ${ }^{19}$.

Assim, segundo essa linha doutrinária, o que de fato é crucial, é analisar qual o núcleo fundante, ou seja, sob quais pressupostos encontra-se alicerceado todo o sistema processual, para assim definir qual é o predomínio conceitual de aplicabilidade das normas no referido sistema processual, e assim, saber se o mesmo detém natureza inquisitória (gestão da prova na mão do juiz) ou acusatória (gestão da prova na mão da parte), sendo que, a partir da identificação deste núcleo, torna-se possível determinar se o sistema processual em questão detém características majoritariamente acusatórias ou inquisitórias.

\section{Uma análise crítica acerca do sistema processual penal brasileiro.}

\footnotetext{
17 NUCCI, Guilherme de Souza. Manual de Processo Penal e Execução Penal. São Paulo: Revista dos Tribunais, 2009, p. 25.

${ }^{18}$ Fazem parte desta corrente vários nomes, dentre os quais, Geraldo Prado, Jacinto Coutinho e Aury Lopes Junior.

${ }^{19}$ LOPES JÚNIOR, Aury. Direito Processual Penal. 15 ed. São Paulo: Editora Saraiva Educação, 2018, p.4142 .
} 
O sistema processual penal brasileiro é apontado por grande parte da doutrina, como um sistema misto, ou seja, trata-se de um sistema inquisitório na primeira fase, a chamada fase pré-processual - na fase do inquérito policial por exemplo -, e um sistema acusatório na segunda fase, a chamada fase processual.

Nesse sentido defende $\mathrm{Nucci}^{20}$ que:

O sistema adotado no Brasil, embora não oficialmente, é o misto. Registrese desde logo que há dois enfoques: o constitucional e o processual. Em outras palavras, se fôssemos seguir exclusivamente o disposto na Constituição Federal, poderíamos até dizer que nosso sistema é acusatório. Ocorre que nosso processo penal é regido por Código específico, que data de 1941, elaborado em nítida ótica inquisitiva. Logo, não há como negar o encontro dos dois lados da moeda resultou no hibridismo que temos hoje. (...) Em suma, apesar de haver alteração no Código de Processo Penal, continua ele com o seu caráter misto (...).

Também nessa linha, leciona Lauria Tucci ${ }^{21}$, que entende:

O moderno processo penal delineia-se inquisitório, substancialmente, na sua essencialidade; e, formalmente, no tocante ao procedimento desenrolado na segunda fase da persecução penal, delineia-se como um processo de caráter acusatório.

Para essa linha doutrinária, portanto, o processo penal brasileiro segue majoritariamente uma linha acusatória, entretanto, reconhece-se que, durante a sua primeira fase (ou fase pré-processual), o processo reveste-se de uma natureza inquisitiva: é cediço que durante o inquérito policial a regra é a predominância do caráter inquisitório, restando evidente o fato de que o averiguado, nesta etapa, detém ferramentas bastante limitadas para exercer seu direito de ampla defesa e o contraditório. Por isso, defende-se que o sistema processual brasileiro é na verdade uma mescla entre inquisitório e acusatório, por isso, chamado misto.

Outros, por sua vez, como Pachelli de Oliveira e Norberto Avena, defendem que o sistema processual brasileiro é, na verdade, um sistema processual puramente acusatório. Segundo esse entendimento, é indiscutivelmente flagrante a existência da separação entre a acusação e o julgador no ordenamento jurídico brasileiro, e isso seria, de fato, a evidência cabal de que o sistema processual penal brasileiro se trata de um sistema acusatório.

${ }^{20}$ NUCCI, Guilherme de Souza. Manual de Processo Penal e Execução Penal. São Paulo: Revista dos Tribunais, 2009, p. 122-124.

${ }^{21}$ TUCCI, Rogério Lauria. Teoria do Direito Processual Penal. São Paulo: Revista dos Tribunais, 2002, p. 38. 
Nessa toada, aqueles que defendem essa visão doutrinária entendem que os poderes de iniciativa probatória do juiz, comprovadamente existentes no ordenamento jurídico brasileiro, podem ser admitidos, não sendo algo que viole o sistema acusatório, contanto que tais poderes sejam exercidos de forma limitada e com base na busca da verdade real. Para essa linha da doutrina, apesar de, reconhecidamente, na fase pré-processual (investigativa) predominarem características inquisitórias, o inquérito policial é destinado exclusivamente à acusação, não podendo ser utilizado diretamente pelo juízo para fundamentar suas decisões e, por isso, não sendo instrumento capaz de violar o princípio acusatório do sistema. ${ }^{22}$

Ademais, como explica Pachelli de Oliveira" 23 "decididamente o inquérito policial não é processo", portanto, não se pode justificar um sistema processual misto por conta das características da fase do inquérito policial, pois ela não faz parte do processo em si. Além disso, o autor entende que não é o juiz que julga o mesmo que acompanha a investigação. Nesse sentido, ele prossegue explicando que:

(...) somente quando (se) a investigação fosse realizada diretamente perante o juízo seria possível vislumbrar contaminação do sistema, sobretudo quando ao mesmo juiz da fase de investigação se reservasse a função de julgamento. Não é esse o caso brasileiro. (...) Convém insistir que o inquérito policial se destina exclusivamente ao órgão da acusação, não se podendo aceitar condenações fundadas em provas produzidas unicamente na fase de investigação (...) não é porque o inquérito policial acompanha a denúncia e segue anexado à ação penal que se pode concluir pela violação da imparcialidade do julgador(...). É para isso que se exige, também, que toda decisão judicial seja necessariamente fundamentada. Decisão sem fundamentação racional ou com fundamento em prova constante unicamente do inquérito é radicalmente nula. Portanto, limitada a iniciativa probatória do juiz brasileiro ao esclarecimento de dúvidas surgidas a partir de provas produzidas pelas partes no processo - e não na fase de investigação - pode-se qualificar o processo penal brasileiro como um modelo de natureza acusatória ${ }^{24}$.

Entendimento semelhante é o de Norberto Avena ${ }^{25}$ :

De fato, vigora no Brasil o sistema acusatório, entendimento este respaldado em diversas decisões do STF e do STJ. Afinal, todos concordam que, embora inexista um dispositivo legal expresso na Constituição Federal de 1988, é dela que se extrai o conjunto de princípios e normas que conduz ao entendimento de que o direito brasileiro agasalhou o sistema acusatório.(...) não foi por outro motivo senão reafirmar o princípio acusatório no sistema processual pátrio, que o legislador, por

\footnotetext{
${ }^{22}$ AVENA, Norberto Cláudio Pâncaro. Processo Penal. 9 ed. São Paulo: Método, 2017, p. 40-41.

${ }^{23}$ PACHELLI DE OLIVEIRA, Eugênio. Curso de Processo Penal. 11 ed. Rio de Janeiro: Lumen Juris, 2009, p.8-9.

${ }^{24}$ Idem

${ }^{25}$ AVENA, Norberto Cláudio Pâncaro. Processo Penal. 9 ed. São Paulo: Método, 2017, p. 41-42.
} 
meio das Leis 11.689/2008 e 11.719/2008, revogou as chamadas prisão da pronúncia e prisão da sentença condenatória recorrível, anteriormente previstas nos arts. $408, \S 1 .^{\circ}$, e 594 do CPP, respectivamente, as quais contemplavam a possibilidade de segregação provisória do réu simplesmente em face de seus maus antecedentes ou da circunstância de não ser primário. Ora, vigorasse entre nós o sistema processual misto, poderiam estas modalidades de custódia continuar presentes no Código de Processo Penal, como resquício válido do sistema inquisitivo.

Interessante também mencionar o que defende Gustavo Badaró ${ }^{26}$ que, embora não cite diretamente que o sistema processual brasileiro é acusatório, menciona que os poderes instrutórios do juiz não representam um perigo a sua imparcialidade, e desde que sejam exercidos na medida correta, não são suficientes para contaminar o processo acusatório. Para o autor, modernamente, o processo acusatório admite que o juiz seja dotado de poderes instrutórios, ou seja, é compatível com um juiz dotado de poderes para determinar, por exemplo, a produção ex officio de provas.

Em derradeiro, existe uma terceira linha doutrinária, composta por autores como Geraldo Prado, Aury Lopes Jr. e outros, que considera que, na realidade, o processo penal brasileiro detém como característica nuclear o sistema inquisitório.

Nesse sentido, defende Lopes $\mathrm{Jr}^{27}$, ao dizer que, embora o processo penal brasileiro ainda seja comummente classificado por grande parte da doutrina como misto, ou seja, inquisitório na primeira fase (inquérito) e acusatório na fase processual, tal entendimento não merece prosperar pois, para o autor, dizer que um sistema processual penal é "misto" é não dizer nada sobre ele, pois "mistos" todos os sistemas processuais na história foram e ainda são. Ele explica que, o ponto crucial para identificar qual é o animus do sistema colocado em estudo, é verificar o seu núcleo, identificando qual é o seu princípio fundante. E finaliza o autor, dizendo que "o processo penal brasileiro é essencialmente inquisitório"

Ou seja, segundo a linha doutrinária em questão, utilizar-se da separação inicial entre acusação e julgador é absolutamente insuficiente para categorizar o sistema processual como acusatório (ou menos ainda misto), uma vez que, ao longo do procedimento, depois de formulada a acusação, o sistema ainda permite que o juiz assuma um papel ativo na busca da prova ou mesmo na prática de atos tipicamente da parte acusadora, como, por exemplo, existir previsão legal para que o juiz requeira a oitiva de testemunhas além daquelas

\footnotetext{
${ }^{26}$ BADARÓ, Gustavo Henrique. Processo Penal. 5 ed. São Paulo: Revista dos Tribunais, 2016, p. 97.

${ }^{27}$ LOPES JÚNIOR, Aury. Direito Processual Penal. 15 ed. São Paulo: Editora Saraiva Educação, 2018, p.47.
} 
indicadas ou determine diligências de ofício a fim de obtenção de provas, como ocorre no processo penal brasileiro.

Nessa linha, leciona $\operatorname{Prado}^{28}$, que explica que:

Entre os poderes do juiz, segundo o princípio acusatório, não se deve encontrar aquele pertinente à investigação judicial, permitindo-se, quando muito, pela coordenação dos princípios constitucionais da justiça material e presunção da inocência, que moderadamente intervenha, durante a instrução, para, na implementação de poderes de assistência ao acusado, pesquisar de maneira supletiva provas da inocência, conforme a(s) tese(s) esposada(s) pela defesa. (...) intervenção judicial na atividade probatória a favor do acusado há de ser moderada, como antes frisamos, enquanto estará interditada em relação à acusação, que nos dias de hoje dispõe de aparato suficientemente bem constituído para pelejar em juízo.

$\mathrm{Na}$ mesma toada, explica Aury Lopes $\mathrm{Jr}^{29}$, dizendo que o sistema penal brasileiro não é misto, e menos ainda acusatório, mas detém um núcleo inquisitório. Ele explica que:

Ainda que se diga que o sistema brasileiro é "misto", a fase processual não é acusatória, mas inquisitória ou neoinquisitória, na medida em que o princípio informador é o inquisitivo, pois a gestão da prova está nas mãos do juiz. Com relação à separação das atividades de acusar e julgar (...) não basta termos uma separação inicial, com o Ministério Público formulando a acusação e depois, ao longo do procedimento, permitir que o juiz assuma um papel ativo na busca da prova ou mesmo na prática de atos tipicamente da parte acusadora.

De fato, tal posicionamento é a hipótese que parece mais correta.

Isso porque, como discorre $\operatorname{Prado}^{30}$, parece bastante coerente o referido entendimento, por exemplo, quando se observa o fato de que o juiz, que segundo o sistema acusatório deve ser tão somente o destinatário da prova, detém a autonomia de produzir a prova de ofício, produzindo uma prova para apresentar para ele mesmo, como é possível ocorrer no sistema brasileiro. Nesses casos, o juiz passa a se colocar como sujeito ativo do conhecimento e a empreender tarefa que não é neutra (produzir a prova do que acredita ser verdade), perdendo então, seu caráter imparcial - e consequentemente ferindo o princípio acusatório previsto na Constituição Federal.

Essa situação é explicada com bastante acuidade pelo autor, que menciona que, no caso brasileiro, a regra de produção de provas pelo juiz, de ofício, tão-só consolida aquilo

\footnotetext{
${ }^{28}$ PRADO, Geraldo. Sistema Acusatório. A conformidade constitucional das Leis Processuais Penais. 3 ed. Rio de Janeiro: Lumen Juris, 2005, p. 218.

${ }^{29}$ LOPES JÚNIOR, Aury. Direito Processual Penal. 15 ed. São Paulo: Editora Saraiva Educação, 2018, p. $47-$ 48.

${ }^{30}$ PRADO, Geraldo. Sistema Acusatório. A conformidade constitucional das Leis Processuais Penais. 3 ed. Rio de Janeiro: Lumen Juris, 2005, p. 224.
} 
que desde as ordenações, passando pelo Código de Processo Criminal do Império, de 29 de novembro de 1832 e pelas Reformas Processuais de 3 de dezembro de 1841 e 20 de setembro de 1871, tornara-se regra em um ambiente em que a Intendência, espécie de Secretaria de Segurança Pública, fora desde o início entregue a um Desembargador, juiz de corte superior. Segundo o autor, a manutenção desse estado de coisas no sistema processual brasileiro não pode ser compreendida como evolução.

Para Prado, a designação artificializada de sistema adversarial, para definir o acusatório em que a inércia probatória do juiz é regra, para distingui-lo de outro sistema acusatório em que o juiz tem poderes instrutórios, atende tão somente o propósito de tentar prolongar a vida do Código de Processo Penal de 1941, oriundo de uma era em que predominava o autoritarismo estatal, naquilo que nele é central, tal seja, a ideia de que se trata de instrumento da política de segurança pública do Estado e não de previsão das regras do devido processo legal, conforme determinado posteriormente pela Constituição de $1988^{31}$.

Dessa forma, o que se observa, de fato, é a existência de um núcleo inquisitório que resiste como base fundante no âmago do sistema processual penal brasileiro, evidenciado pelos inúmeros dispositivos que atribuem ao juiz a possibilidade de solicitar produção de provas e de tomar medidas de ofício, o que enseja em uma flagrante inconstitucionalidade, uma vez que, como explica, a Constituição Federal de 88 “rege-se por um processo penal acusatório, fundado nos princípios do contraditório, ampla defesa e imparcialidade do juiz." 32 .

Assim, uma vez adotado o mencionado posicionamento, o trabalho passa a apresentar uma hipótese de resolução para essa flagrante incompatibilidade entre os diversos dispositivos presentes no Código de Processo Penal e o sistema acusatório constitucionalmente consagrado.

\section{Da inconstitucionalidade do sistema processual penal vigente no Brasil.}

\footnotetext{
${ }^{31}$ PRADO, Geraldo. Sistema Acusatório. A conformidade constitucional das Leis Processuais Penais. 3 ed. Rio de Janeiro: Lumen Juris, 2005, p. 223-226.

${ }^{32}$ LOPES JÚNIOR, Aury. Direito Processual Penal. 15 ed. São Paulo: Editora Saraiva Educação, 2018, p. 49.
} 
Como mencionado, é praticamente unânime o entendimento de que a Constituição Federal de 88 estabelece o sistema acusatório como o sistema processual penal alinhado aos preceitos defendidos pela carta magna e como sendo o sistema em vigor no ordenamento jurídico brasileiro atualmente. Entretanto, ao analisar-se o Código de Processo Penal, é possível notar uma série de dispositivos incompatíveis com o sistema acusatório.

Vide, por exemplo, o art. 156 do Código de Processo Penal, que faculta ao juiz, de ofício, ordenar a produção de provas que lhe pareçam úteis na "busca da verdade real", ou o art. 385 do CPP, que autoriza ao juiz a proferir sentença condenatória, ainda que a acusação pleiteie pela absolvição do acusado, além de muitos outros, como o art. 310, II, que autoriza ao juiz converter a prisão em flagrante em preventiva na audiência de custódia, mesmo sem pleito por parte da acusação (apesar de que tal questão divide a jurisprudência); art. 242, que autoriza que o juiz determine busca pessoal ou domiciliar de ofício, sem necessariamente existir requerimento da acusação; art. 127, que autoriza ao juiz ordenar o sequestro dos bens do averiguado ou denunciado, também sem a necessidade do requerimento ministerial; art. 209, que autoriza ao juiz ouvir testemunhas além daquelas indicadas pelas partes, se assim julgar necessário; art. 196 que autoriza o juiz a proceder com novo interrogatório, também de ofício, quando julgar pertinente; art. 383, que permite que o juiz, de ofício, atribua definição jurídica mais grave do que aquela apontada pelo Parquet à conduta descrita na denúncia, se assim achar conveniente, entre outros exemplos.

Além disso, no processo penal brasileiro, se tem uma acusação formal (denúncia) que é acompanhada de um inquérito policial inquisitorial; um juiz que, no mais das vezes, já se manifestou na fase de investigação preliminar - e, portanto, já está psicologicamente vinculado a um pré-juízo, no mais das vezes em desfavor do réu -; um processo escrito e extremamente burocrático, quase sem oralidade, bem como (e principalmente) um juiz que detém autonomia para determinar a produção das provas que entender cabíveis para alcançar a "verdade real", inclusive produzindo as provas de ofício, na maior parte dos casos, prejudiciais ao réu.

Ao analisar-se a referida situação, bem como a série de dispositivos completamente dissonantes do princípio constitucional acusatório, é possível verificar que o Código de Processo Penal brasileiro (e algumas legislações especiais também) detém, na verdade, um princípio nuclear flagrantemente inquisitório, o que resulta em uma flagrante inconstitucionalidade da referida legislação, na forma que vigora. Nesse sentido, "é evidente 
que as leis processuais ordinárias brasileiras, de acordo com a maneira como estão sendo aplicadas, não respeitam totalmente as fronteiras traçadas pelo princípio acusatório" ${ }^{33}$.

Dessa forma, a hipótese que se pretende levantar, é de que, em um primeiro momento, seria necessário admitir o que, nesta ocasião, se entende ser um equívoco: devese parar de tratar o sistema processual penal brasileiro como um sistema misto e passar a identificar qual seria o seu núcleo regente. Isso porque, como já mencionado, na realidade, todos os sistemas processuais contemporâneos são, na verdade, sistemas mistos, sendo os modelos puros somente uma referência histórica. Por ser um sistema misto (como todos os outros), é crucial analisar qual é a prevalência estrutural do sistema brasileiro - inquisitivo ou acusatório.

A partir daí, é preciso então verificar o princípio regente no processo penal brasileiro, que após a análise das questões suscitadas, a hipótese que se defende é de que no ordenamento jurídico infraconstitucional brasileiro evidencia-se a proeminência do sistema inquisitório.

Cumpre ressaltar que a despeito de respeitável, a corrente doutrinária que defende a separação das funções de acusar e julgar seria suficiente para configurar um sistema processual penal de núcleo acusatório, como já mencionado, não parece correta. A esse respeito, explica Lopes $\mathrm{Jr}^{34}$, que diz que "a noção de que a (mera) separação das funções de acusar e julgar seria suficiente e fundante do sistema acusatório é uma concepção reducionista, na medida em que de nada serve a separação inicial das funções se depois se permite que o juiz tenha iniciativa probatória."

Assim, uma vez constatado o princípio nuclear do Código de Processo Penal como atrelado ao sistema inquisitório, restaria evidenciada a incompatibilidade da base principiológica vigente com o Sistema Processual Acusatório, e consequentemente com a Constituição Federal, o que tornaria possível justificar a necessidade de uma ampla e profunda reforma na legislação processual penal brasileira, o que tornaria possível ao legislador adequar a aplicação da lei processual aos ditames constitucionais do Estado

\footnotetext{
${ }^{33}$ PRADO, Geraldo. Sistema Acusatório. A conformidade constitucional das Leis Processuais Penais. 3 ed. Rio de Janeiro: Lumen Juris, 2005, p. 385.

${ }^{34}$ LOPES JÚNIOR, Aury. Direito Processual Penal. 15 ed. São Paulo: Editora Saraiva Educação, 2018, p. 45 46.
} 
Democrático de Direito pós 88 e efetivar o sistema acusatório no sistema processual penal brasileiro.

Uma reforma de tamanha amplitude não seria novidade no mundo ocidental, longe disso. No Chile, por exemplo, uma ampla reforma foi realizada em meados de entre $2001 \mathrm{e}$ 2005, com o intuito de adequar o sistema processual penal daquele país ao sistema acusatório.

Naquele país, o processo passou a deter 3 etapas: a primeira é presidida por um chamado "juízo de garantias”, em que se verifica, através de uma audiência de formulação de imputação, a legalidade de uma eventual prisão preventiva e a validade dos atos préprocessuais; a segunda é a chamada "etapa intermediária”, na qual um outro juiz analisará se as provas colhidas pela acusação (podendo também ser produzidas pela defesa) são legais e podem ser usadas na terceira fase do procedimento, em que ocorrerá a análise meritória; e a terceira fase, o chamado o "juízo oral", que se trata de uma fase instrutória, na qual ocorre finalmente o julgamento após uma audiência pautada no princípio da oralidade, a ser realizado por três juízes que não tiveram nenhuma espécie de contato com a produção de provas ou com quaisquer elementos do processo anteriormente, garantindo-se a imparcialidade.

Tais mudanças, além de evidentemente mais alinhadas ao sistema processual acusatório, e em consonância com os tratados internacionais que regem as democracias ocidentais, aparentam estar trazendo mudanças perceptíveis na sociedade chilena, como por exemplo, na redução significativa do número de presos provisórios no Chile, que, segundo dados do Ministério da Justiça chileno, representavam cerca de $48 \%$ do total de pessoas presas naquele país e, após as reformas, passaram a representar somente $12 \%$ desse total ${ }^{35}$.

Essa queda considerável, se deve, provavelmente, à mudança nuclear do sistema processual penal daquele país, que migrou para um sistema mais justo e coerente para com os princípios fundamentais regentes de um Estado Democrático de Direito. Assim, o que que se defende, como uma possível forma de enfrentamento ao problema apresentado, seria a realização, a exemplo do ocorrido no Chile, de uma ampla reforma infraconstitucional no Brasil.

\footnotetext{
${ }^{35}$ Dados obtidos do Ministério da Justiça chileno. Disponível em: https://www.minjusticia.gob.cl/10-anos-dela-reforma-procesal-penal/. Acesso em: 04 de ago. 2020
} 
Ou seja, entende-se que não seria possível a realização, tão somente, de uma filtragem constitucional na legislação infraconstitucional brasileira. Isso porque, como já mencionado anteriormente, o "espírito" entranhado na legislação infraconstitucional brasileira detém em seu cerne um caráter inquisitório e eventuais modificações pontuais seriam insuficientes para alinhar o Código de Processo Penal e as demais legislações ao princípio constitucional acusatório.

Assim, haja vista que, ao promulgar-se a Constituição Federal em 1988, o constituinte brasileiro optou pela implementação de um sistema processual penal acusatório, e diante do fato de que o ordenamento jurídico processual, mesmo após uma série de modificações pontuais, ainda está muito distante de ser, de fato, um sistema acusatório, o que se propõe como única solução para a resolução desta incompatibilidade é uma ampla reforma processual no Brasil, a exemplo da ocorrida no Chile, para que "coloque-se de lado a aparência acusatória e efetive-se a estrutura que, democraticamente, divide tarefas, funções e responsabilidades." ${ }^{36}$

\section{CONSIDERAÇÕES FINAIS.}

Os sistemas processuais penais, como parte do Direito e reflexo da sociedade em que se encontram inseridos, foram sendo modificados ao longo do tempo, ganhando e perdendo características mais ou menos acusatórias ou inquisitórias, a depender do tempo, local e sociedade em que se encontram inseridos. De fato, no Brasil, principalmente após a constituição cidadã de 1988, a justificativa base do sistema inquisitório, que é alicerceada em uma suposta garantia à ordem pública, passou a ser repensada de forma bastante progressista, haja vista a necessidade de redemocratização de um país recém imerso em uma série de governos autoritários.

Assim, tomando como base os princípios fundamentais que foram consagrados na democrática carta magna brasileira, o sistema processual penal brasileiro não poderia ser outro que não o acusatório, o qual, na presente ocasião, defende-se como o um modelo

\footnotetext{
${ }^{36}$ PRADO, Geraldo. Sistema Acusatório. A conformidade constitucional das Leis Processuais Penais. 3 ed. Rio de Janeiro: Lumen Juris, 2005, p. 366.
} 
processual ideal para o funcionamento de um Estado Democrático de Direito, não sendo possível vislumbrar algum outro modelo de sistema processual que seja mais condizente com os direitos fundamentais previstos na Constituição Cidadã, sejam os sistemas processuais tradicionalmente elencados pela doutrina e explicados no presente artigo ou não. Isso porque, caso fosse diferente, todo o sistema processual penal do país estaria condenado ao inconstitucionalismo flagrante, pois as normas regentes consagradas no ordenamento jurídico supremo, as quais encontram-se consonantes com os Direitos Humanos Internacionais e com a maioria dos ordenamentos jurídicos dos demais países democráticos ocidentes, não são passíveis de acolher normas infraconstitucionais pautadas em um sistema inquisitório ou autoritário.

Ocorre que, o Código de Processo Penal brasileiro data de 1941, momento no qual a sociedade brasileira atravessava um período em que o Estado exercia um controle social extremamente autoritário, e, como cediço, a mesma lei ainda vigora no país, mesmo após todas as alterações sociais e estruturais de cunho progressista e democráticas vivenciadas no país nos últimos anos.

De fato, foram feitas diversas alterações pontuais na lei ao longo dos anos, numa tentativa do legislativo de adaptar o antiquado apanhado de normas à sociedade democrática dos dias de hoje. Ou seja, várias foram as mudanças na legislação processual penal, com o intuito de tornar o sistema "mais acusatório", e assim, eliminar as incompatibilidades entre o Código de Processo Penal de 1941 e a Constituição Federal de 1988. Infelizmente, essa não parece ser a opção mais correta.

Isso porque, como foi demonstrado, um sistema processual detém sempre um núcleo principiológico regente. No caso do Código de Processo Penal de 1941, o núcleo principiológico da legislação é reflexo da sociedade e da época em que entrou em vigor, ou seja, a legislação detém um núcleo principiológico condizente com seu tempo, em que o Estado era autoritário e a garantia da ordem pública era mantida em um pedestal e os direitos fundamentais individuais eram suprimidos sem maiores objeções.

Assim, modificações pontuais não são suficientes para substituir o "espírito" da lei. Prova disto é que, apesar de ter sofrido dezenas de alterações ao longo do tempo, ainda é possível identificar diversos artigos no Código de Processo Penal, alguns inclusive citados no presente artigo, que violam de maneira gritante o princípio acusatório, que deveria, supostamente, vigorar em nosso ordenamento jurídico nos dias atuais. 
O que de fato ocorre no Brasil, é uma inércia injustificada que perdura por anos dos poderes constituídos, em especial, do Poder Legislativo, que insiste em fazer alterações pontuais na legislação vigente, numa tentativa de mantê-la operando dentro dos ditames constitucionais, tentativa essa que, segundo a linha defendida no presente artigo, vem se mostrando absolutamente infrutífera em corrigir as inconstitucionalidades presentes no Código de Processo Penal, gerando grande insegurança jurídica e incessantes, repetitivos e cansativos debates no Judiciário.

Dessa forma, não resta outro modo a não ser uma ampla e profunda reforma no sistema processual penal brasileiro, que ponha fim à já combalida legislação de 1941, cessando assim de uma vez por todas o processo de constante adaptação pontual que vem sendo realizado ano após ano no Código de Processo Penal e que vem transformando o sistema processual penal brasileiro em uma verdadeira colcha de retalhos inconstitucional.

\section{REFERÊECIAS:}

ARAGONESES ALONSO, Pedro. Curso de Derecho Procesal Penal. V. 1. 4 ed. Madrid: Prensa Castellana, 1974, p. 42.

AVENA, Norberto Cláudio Pâncaro. Processo Penal. 9 ed. São Paulo: Método, 2017.

BADARÓ, Gustavo Henrique. Processo Penal. 5 ed. São Paulo: Revista dos Tribunais, 2016.

CARNELUTTI, Francesco. Lecciones sobre el Processo Penal. V. 03. Buenos Aires: Bosh, 1950.

COUTINHO, Jacinto Nelson de Miranda. O papel do novo juiz no processo penal. In: Crítica à teoria geral do direito processo penal. Rio /de Janeiro: Renovar, 2001.

CUNHA MARTINS, Rui. O Ponto Cego do Direito. Rio de Janeiro: Lumen Juris, 2010.

FERRAJOLI, Luigi. Direito e razão: teoria do garantismo penal. 2 ed. São Paulo: Revista dos Tribunais, 2006.

FUNDAÇÃO GETÚLIO VARGAS. Dicionário de Ciências Sociais da Fundação Getúlio Vargas. Rio de Janeiro: FGV, 1986.

LEONE, Giovanni. Manuale di Diritto Processuale Penale. Napoli: Jovene, 1983.

LOPES JÚNIOR, Aury. Direito Processual Penal. 15 ed. São Paulo: Editora Saraiva Educação, 2018. 
Revista Eletrônica de Direito Processual - REDP.

Rio de Janeiro. Ano 16. Volume 23. Número 1. Janeiro a Abril de 2022

Periódico Quadrimestral da Pós-Graduação Stricto Sensu em Direito Processual da UERJ

Patrono: José Carlos Barbosa Moreira (in mem.). ISSN 1982-7636. pp. 1188-1207 www.redp.uerj.br

NUCCI, Guilherme de Souza. Manual de Processo Penal e Execução Penal. São Paulo: Revista dos Tribunais, 2009.

PACHELli DE OLIVEIRA, Eugênio. Curso de Processo Penal. 11 ed. Rio de Janeiro: Lumen Juris, 2009.

PRADO, Geraldo. Sistema Acusatório. A conformidade constitucional das Leis Processuais Penais. 3 ed. Rio de Janeiro: Lumen Juris, 2005.

ROCHA, Cármem Lúcia Antunes. O Princípio Constitucional da Igualdade. Belo Horizonte: Lê, 1990

TUCCI, Rogério Lauria. Teoria do Direito Processual Penal. São Paulo: Revista dos Tribunais, 2002. 